This is an open access article under the terms of the CC-BY 3.0 License.

Peer review method: Double-Blind

Date of acceptance: November 16, 2020

Date of publication: January 08,2021

Original scientific article

DOI: https://www.doi.org/10.47305/JLIA2163011u

\title{
EVOLUTIONARY POSSIBILITIES OF DEMOCRATIZATION AND ATAVISTIC NATIONALISM: A COMPARATIVE STUDY OF UNRECOGNIZED STATES
}

\author{
Hilmi Ulas \\ Chapman University, California, USA \\ ORCID iD: https://orcid.org/0000-0001-5759-539X \\ ulas@chapman.edu
}

\begin{abstract}
The question of how rising atavistic nationalism will affect democracies worldwide is an essential one of our time. In this paper, I focus instead on conducting a comparative historical analysis of atavistic nationalism in two unrecognized states: North Cyprus and Taiwan. I argue that the democratic crisis of our times is, in its essence, economic and has been precipitated by the failure of democracies to build domestic capacities to support democratic values. Furthermore, I posit that engaging populaces at the local political level will prove essential to preserving democracies around the world. I conclude by underlining that atavistic nationalism is indeed a significant threat to regional and global peace and requires further co-operation on trade and governance, and should be engaged at the local level. Lastly, I suggest that co-creating local cultures that will act to soften atavistic nationalism, which feeds off the perception of threats and fear.
\end{abstract}

Keywords: Unrecognized States; Democratization; Atavistic Nationalism; Economic Crises; Narrative Positioning; Taiwan; North Cyprus 


\section{INTRODUCTION}

Atavistic nationalism refers to the new and widespread model of the extremist ideology that promotes exclusive political identities based on the group's everlasting, nobler nature as a 'truth of history,' about an 'imagined reality'. Nationalist ideologies are making a strong comeback around the globe, whereas democracy as a form of governance is simultaneously on a worldwide decline (The Economist 2018; Freedom House 2017). In fact, in conjunction with a rise in the popularity of right-wing ideologies, de-democratization has occurred in advanced democracies (The Economist 2018). This defies the theoretical assumption that consolidated democracies will not retreat. However, as consolidated democracies de-democratize, both scholars and policymakers must further their understanding of the dynamics of democracy in an age of atavistic nationalism.

This paper aims to capture the complex long-term dynamics of nationalism and to inform scholars and policymakers on how to positively engage pushes for unity in a pluralistic society. Nationalism, however, is a narrative process that develops over an extended time - requiring a longitudinal and historical study - whereas it is a relatively recent occurrence within advanced democracies. Therefore, scholars need to identify and study cases where atavistic nationalism has been active for decades to produce a comprehensive study. For this purpose, I study the evolutions of North Cyprus and Taiwan through a comparative historical analysis. Thereafter, I argue that the democratic crisis of our times is, in its essence, economic and has been precipitated by the failure of democracies to build domestic, democratic capacities. I conclude by underlining that atavistic nationalism is a significant threat to regional and global peace and offer suggestions on how to deal with this threat constructively.

\section{ATAVISTIC NATIONALISM}

\section{Defining Atavistic Nationalism}

Nationalism is generally defined as a political tendency to prioritize an exclusive group in the use of the political resources of a state (Verkhovskii and Pain 2012, 52). However, the nature of nationalism, i.e. whether it is a destructive or constructive political force, has long been debated. Mishra underlines the rise of nationalism in the USA as a moment that can function as the crisis needed to jumpstart American democracy (Mishra 2017). Some other scholars who study the democratic transitions of ex-colonial states underline that the transition process was facilitated by a rising sense of nationalism (Brudny and Finkel 2011; Sabatovych 2017; Surzhko-Harned 2010). Nevertheless, most scholars instead argue that nationalism is a threat to peace at all levels - domestic, regional, and global (Bonikowski 2016; Conversi 2012; GrigorSuny 
2017). The literature also underlines that a nation can be defined in one of two ways: civically or ethnocentrically. On the one hand, civic nationalism, where all citizens are afforded the same rights and privileges, can promote loyalty to the state and its democracy. This evolving nationalism espouses the democratic values of liberty, equality, and sovereignty, thus paving the way to a deep democracy (Sabatovych 2017, 1); (Fukuyama 1992). On the other hand, ethnocentric nationalism instead aims to not only achieve cultural homogeneity but also render state power exclusive (Dyrstad 2012, 818). This is antithetical to democracy.

Mostly, nationalism relies upon existing inter-group boundaries based on ethnicity and religion to promote cultural homogeneity, despite inherent societal heterogeneity (Sabatovych 2017, 4). Elites then attempt to utilize this sense of unity to create a self-sustaining system of legitimacy and thus win re-elections (Conversi 2012, 789). It is important to note that whether nationalism promotes democracy is therefore based on the will of the political elite, moderated by the extent of political mobilizations at the social level as well as the extent of societal cleavages (Sabatovych 2017, 18). Therefore, nationalism should not be treated simply as a malady.

Atavistic nationalism is a special type of ethnocentric and classist nationalism. Much as with other nationalist movements, atavistic nationalism is driven by an 'Us vs. Other' mentality (Gingrich 2006; Volkan 1998). What makes the current atavistic nationalism distinct are three factors (modified from Gingrich's typology (Gingrich 2006, 199-200)): tripartite hierarchy (elites-us-immigrants or multinational organizations-usimmigrants); fear-driven: fear of losing (globalization; capitalism) and fear of invasion/being taken advantage of (integrationist policies, terrorism, or neocolonization); hope driven: spurred on by a mythical past and/or future of prosperity and security.

\section{The Unrecognized States and Atavistic Nationalism}

The unrecognized states have only recently come to be studied. Nevertheless, there is an agreement that these entities feature the following characteristics: a) a violent, unilateral secession from a parent state, whose de jure territories this new entity claims and controls de facto; b) independently existing for more than four years, running state institutions; c) lack of recognition by a majority of the international community (non-recognition); d) exhibiting high internal legitimacy and low external legitimacy; and lastly e) they are not completely dependent on any other state for policy-making and domestic affairs.

The relationship between atavistic nationalism and unrecognized states is significant: unrecognized states are born of and driven by incompatible forms of atavistic nationalism (Mulaj 2011, 43). Therefore, studying unrecognized states is critical for scholars to explain the dynamics of atavistic nationalism, as well as how and why it 
can pave the way for either de-democratization or democratization. While atavistic nationalism threatens human rights and democracy, the existing global and local institutions have yet to put forth a coherent agenda to address this threat. Therefore, the scholarly community needs to explore this phenomenon by studying critical cases, such as unrecognized states.

\section{CASE STUDIES: ORIGINS AND EVOLUTIONS OF ATAVISTIC NATIONALISM}

North Cyprus

The Turkish Cypriot people are one of the two official communities inhabiting the island of Cyprus and a founding partner of the Republic of Cyprus. Due to a Greek military coup d'état on the island in 1974, which turned violent, the Turkish military intervened through the 'Happy Peace Operation' - what many perceive as an invasion dividing the island physically into two. Negotiations to reunite the island went fruitless for nine years and the Turkish Cypriot community, through the will of its political leader - Rauf Denktash - and his Turkish military backing, unilaterally declared independence. They established the Turkish Republic of Northern Cyprus (TRNC or NC) in 1983.

Denktash was a political figure who established himself as the symbol of Turkish Cypriot independence and created a network of patronage around his hero image, thus monopolizing political power (Isachenko 2012, 44-45). From its establishment until 2000, NC was ruled by corruption and a patronage network built on the distribution of plundered resources (leftover from the displaced Greek Cypriots) and the aid from Turkey (Duzgun 2000, 29), which created a two-layered dependence economy. However, this network was kept somewhat in check by the Turkish Cypriot history of democratic governance and the democratic infrastructure inherited from the Republic of Cyprus. Therefore, the political system of NC was stably semi-democratic, but featured an overpowered executive supported by the independent armed forces of another state.

This system self-legitimized in an atavistic fashion: that the Turkish Cypriots were simply Turks and that they had to be grateful to Turkey for being saved. Furthermore, by tying the Turkish Cypriots to Turkey so closely, Denktash would help the community returns to its 'prosperous times' of the Ottoman era on the island. Additionally, the only guarantee for Turkish Cypriot security and prosperity was through the reinforcement of the Turkish Cypriot ties with Turkey. Turkey was the 'Motherland' that would feed and develop NC. During this era, those who sought to argue for peacemaking with the Greek Cypriots or those who defined themselves as Cypriots (rather than Turks or Turkish Cypriots) were labeled as traitors (Duzgun 2000, 20), with Denktash claiming that only the donkeys of Cyprus were Cypriot (Isachenko 2012, 65, 69). This atavistic identity was disbursed through state-controlled media and schools, as well as symbols such as flags (Navaro-Yashin 2012, 18; 2006); however, it alienated a majority of the island's 
population due to its refusal of a Cypriot culture or identity (Duzgun 2000,69; Isachenko $2012,47)$. This was a well-established atavistic system: a hierarchy of the world-a Turkic us-the 'traitors'; driven by a fear of losing political independence, plundered gains, and of a return to communal strife; and driven by the hope of remaining independent and prospering through the aid of the 'Motherland' (Duzgun 2000, 77). Additionally, the Turkish Cypriot politics and institutions self-organized under the effect of atavistic nationalism in such a way as to allow Denktash and the nationalists to monopolize political power perpetually. Up to today, the nationalists hold circa $50 \%$ of the popular vote despite widespread and documented corruption and ineffective governance.

The rise of atavistic nationalism in Turkish Cypriot politics was facilitated by Denktash's self-promoted war hero image and the support of the armed forces that reported to - as they still do - Turkey. Ultimately, this process allowed for an individual to establish a virtual throne that went uncontested despite widespread nepotism, corruption, and authoritarian behavior including the suppression of the civil society and the media (Duzgun 2000, 296; Isachenko 2012, 109). Such a process supports the ethnosymbolic conceptualization of nationalism where the notion of the 'nation' is created, reinforced, and perpetuated using symbolism ('Motherland', war hero, etc.), melded with both an imaginary ideal (the Ottoman times) and an 'imminent' threat (forceful reintegration and oppression). Furthermore, this also supports the assertion that nationalism is less about loyalty to a flag or a group that existed primordially and instead more about where a person might find economic prosperity and security (Isachenko 2012).

The essential question, then, is as such: how did the prominence of atavistic nationalism help shape the evolution of the Turkish Cypriot political system? It was not until huge economic crises that undermined both the Turkish and Turkish Cypriot economies in 2000 and 2002, which decreased their ability to use day-saving economic aid and plunder to band-aid the festering wound that was a mishandled and unproductive economic policy, that significant opposition was able to rise (Loizides 2015, 181). Furthermore, these crises coincided with the Annan Plan negotiations in Cyprus, where the Turkish Cypriots had the illusory hope of being reintegrated with the international community both economically and socially by reintegrating with the Republic of Cyprus and becoming members of the EU. The popular perception went that if the Turkish Cypriot community accepted a reintegration as proposed, they would receive economic and social benefits even if the plan failed. Furthermore, they held the chance of full EU membership should they reintegrate (Loizides 2015, 181). As such, the opportunity - mainly economic - posed by reintegration exceeded the nationalist rhetoric's ability to threaten or provide hope. Therefore, a considerable opposition gathered, and the non-nationalist parties capitalized on this momentum, displacing Denktash (Isachenko 2012, 146). Eventually, the Turkish Cypriots voted overwhelmingly to affirm the Annan Plan in a communal referendum. 
However, after the Republic of Cyprus rejected the Plan and entered the EU as a full member, the Turkish Cypriots' lot did not improve. Indeed, increased democratization and Europeanization did not generate either recognition or prosperity, which undermined the newly-generated trust in the international community, the reformist elites, and the local and international CSOs (Isachenko 2012, 112). Ultimately, this undermined the new narrative of prosperity through democratization and Europeanization, allowing for a nationalist resurgence, whereby the status quo ante-i.e. nepotism, corruption, repression, executive overreach - re-emerged. Meanwhile, due to the schism with the Turkic atavism and the efforts of the opposition in asserting a distinctly Cypriot identity, a new atavistic narrative against Turkish immigrants was created. Due to this new atavism, the immigrants to NC are discriminated against and not integrated, and there is political polarization which has stopped the democratic gears in the NC.

Overall, atavistic nationalism emerged as the result of the ruling elites' ability to create a self-perpetuating, vote-earning system: firstly, they controlled natural resources and international aid, thus creating patronage networks to either bind or co-opt or subvert critical opposition elites; secondly, they effectively utilized symbolism, fear, and hope - as well as the media and educational facilities that they controlled - to promote nationalist voting blocs among the populace. Furthermore, while the former dynamic is de facto nepotism and corruption, which normally causes loss of votes and thus political power, the latter dynamic allowed for such actions to be tolerated, as war heroes deserved exceptional treatment. As such, the nationalists that held power during the violent era of the Cypriot Conflict extended their power into a new, more pluralistic era. This only changed when the patron-client system ran out of resources while the 'fear' of unsustainable economics and the 'hope' of better trading opportunities displaced the nationalist narrative. Nevertheless, the system and institutions built around atavistic nationalism allowed for the easy re-emergence of the nationalist wing at the first failure of the alternative elites, demonstrating the persistence of the nationalist wing whence in power. Moreover, counter-atavism is just as destructive: it is discriminatory against identified 'others' and has further polarized the Turkish Cypriot community.

\section{Taiwan (Republic of China)}

Taiwan - officially named the Republic of China (ROC) - is an unrecognized state situated in the South China Sea. It seceded from the People's Republic of China (PRC) in 1945 , although both the ROC and the PRC officially claim to represent all of China - and the latter threaten military measures in case the former officially declares independence, defying the One China Policy (Chu 1996, 80). Both its non-recognition and the evolution of its nationalism are unique, which render Taiwan a critical case within this study. 
Taiwan - made up of three islands in the South China Sea - was under the colonial control of the Japanese until 1943, where its administration was taken over by China, which had an ancestral claim to the islands. However, not only did the Mainlander Chinese discriminate against the 'Japan-ified' Taiwanese, but they also ruled the island with iron fists. This created a Mainlander vs. Native divide that was an unbridgeable chasm until 1979. The Taiwanese were excluded from higher government positions and the Kuomintang (KMT - the Chinese political party in a single-party system) appointed its members to the legislature for lifelong terms. Furthermore, the fist of the KMT got heavier as the power-holders of the Mainland lost their Civil War against the Communist Party of China and had to retreat to Taiwan. The KMT was paranoid regarding the spread of 'the communist disease'. They, therefore, enacted complete repression as well as Martial Law, which led to many casualties and arbitrary arrests through a military response to widespread protests in Taiwan. For decades, the KMT ran roughshod whereas the natives took their politics - and their resistance -underground, waiting for an opportune moment while building their capacity (Chu 1996; Gold 1986, 52).

Until the mid-70s, due to the effects of the Cold War, whereby Taiwan posed as a crucial ally against Chinese Communism, the West not only recognized the ROC as the sovereign of all of China, but they also did not scrutinize domestic Taiwanese affairs. This allowed for widespread human rights abuses, authoritarianism, and repression (Chu 1996, 76). However, as the communist threat faded, so did the stock of the KMT. The ROC started to rapidly lose recognition and its sponsor, the USA, debated aid to Taiwan on the grounds of the KMT's human rights violations. This created the political space for the underground Taiwanese network to emerge into power openly (Phillips 2016, 672).

While the military power was still held by the Mainlanders, which disallowed violent means of revolution, the state's repressive capacity had declined due to the removal of Western support (Chou and Nathan 1987; Phillips 2016, 668). Furthermore, the oppressed Taiwanese majority had gained economic might external to the government and was well-organized. As such, when widespread protests in Kaohsiung were met with repression in late 1979, the detractors went even further and the KMT realized that its iron fist policies were not sustainable. This held especially true as Chiang Kai-Shek, the founder around whom the Mainlander patronage networks revolved, had passed away. Therefore, the new KMT leadership was willing to compromise. Successive democratic reforms followed, including the lifting of the Martial Law in 1986, allowing for the formation of a second party, the holding of popular elections in 1996, and the first peaceful transfer of power in 2000.

There were two attempts at utilizing atavistic nationalism in the case of Taiwan; one was both ineffective and negative, whereas the other was the exact opposite. To begin with, the Chinese Mainlanders saw themselves as above the natives. As such, they positioned themselves against the PRC as well as the native majority. Furthermore, this narrative ignored the fears of the Taiwanese vis-à-vis re-colonization and repression 
(based on their experience with the Japanese). Instead, the narrative focused on promoting threat perceptions regarding China and the communist disease, while also giving hope that the ROC would experience a future resurgence and regain control of all of China. Further facilitated by the founder's establishment of a patronage network that was almost completely exclusive to the Mainlanders, this nationalist narrative succeeded in promoting a distinctly Chinese identity in the Mainlanders, which excluded the Taiwanese. Not surprisingly, this type of atavistic nationalism, where a minority not only distinguishes itself from but also aims to suppress the majority, failed once the latter gained power. Instead, this attempt at nationalism caused the creation of a Taiwanese national narrative.

Indeed, the Taiwanese did not develop a distinct sense of self as a nation until after their experiences with the KMT. When they did, as instrumentalized by opposition politicians, they positioned themselves against both the PRC and the KMT (Chu, Diamond, and Templeman 2016, 13). Fearing a return to Mainlander dictatorship or the loss of popular political power, the Taiwanese instead pursued and succeeded in democratization (Phillips 2016). Furthermore, this narrative included hopes: of the Taiwanese for gaining political power; of avoiding reintegration with China; and of pushing for recognition. Meanwhile, due to the lingering Mainlander influence in politics, Chinese threats (requiring the incorporation of Chinese concerns into the body politique), and the fact that the Taiwanese were divided within (there are three native groups) allowed for the emergence of a civic type of atavistic identity (Phillips 2016). Currently, this narrative is suffering from polarization, however, vis-à-vis how to deal with China: whether the Taiwanese should push for independence or create cooperative ties with the economic giant next door (Diamond 2001; Zuo 2016). Nevertheless, the intra-group differences and the power balance among the groups, coupled with the lack of the myth of a primordial Taiwanese nation, will likely ensure that the narrative remains civic.

\section{Analysis: Two Evolutionary Paths of Atavistic Nationalism}

Both cases explored in this article differ greatly regarding their geographical position, demographic outlook, and economic performance. Aside from not being landlocked - which is an important variable regarding state-building dynamics - the two other common points among them were non-recognition and the use of atavistic nationalism for nation-building. Nevertheless, the cases of atavistic nationalism in North Cyprus and Taiwan demonstrated both significant similarities and significant differences, which are analytically important for understanding the evolution of similar narratives arising in the Western democracies and Asia - among others. The findings of the present study validate the model of atavistic nationalism that was adopted herein. 
Firstly, the movements towards creating an atavistic nationalist identity covered in these cases - regardless of whether they resulted in an ethnic or civic interpretation thrived on a tripartite where the 'us' was threatened by not only more powerful, external 'others' but also less powerful, internal 'others'. The former ranged from parent states to the international community at large, whereas the latter ranged from immigrant populations to domestic 'traitors'. This positioning allowed for the assumption of victimhood and potential threat narratives.

Secondly, the movements towards atavism utilized both fear-based and hopebased rhetoric - pointing out real, perceived, or even hypothetical (faith-based) possibilities - to underline the importance of ethnic nationalism. On the one hand, the threats served the functions of not only isolating the targeted community from the identified others but also for having an easy target to scapegoat, such as the disempowered immigrant populations, for the community's woes. On the other hand, the elusive hope functioned to justify the measures taken by the nationalists to get to the desired future by any means possible and to help the community endure hardships 'for a better tomorrow'. However, while the similarities suggested by the model were indeed observed, there were further findings that fell outside the scope of the model: patronage networks.

Indeed, the analyzed attempts at defining nationalism in an atavistic fashion revolved around a 'heroic' figure - the prototype (Volkan 1998) - and the patron-client relationships built around his patronage. These figures espoused a stance of strength and came from the traditionally-powerful class and gender: a well-educated, Turkic Cypriot male; and a Mainlander male leader with political and military backgrounds. Furthermore, they centralized the control of the state's economic resources which they used to 'cement' alliances and to co-opt 'moderate' opposition. This high level of bought support, coupled with their unimpeachable 'heroism', made them untouchable and rendered their opposition immoral by default, which facilitated the nationalist narrative.

Furthermore, in both cases, state-controlled institutions played a critical role. Indeed, in both North Cyprus and Taiwan, the government used media and education to disseminate the idea that the 'us' was inherently Turkic or Chinese/Taiwanese, respectively. Moreover, in Taiwan, the official state language and the educational language both were adjusted to be Chinese to promote Sino nationalism, whereas the same was done to promote nativist nationalism. Therefore, it appears that atavistic nationalism requires the support of a powerful league of political elites' promotion, as well as the use of state-controlled institutions, to take hold. Then, what do the differences among the cases reveal?

First and foremost, 'cultural homogeneity' - real or perceived - matters. Indeed, atavistic nationalism was an easier sell within communities that had more inherent unity - such as the Turkish Cypriots, Mainlanders, or the Native Taiwanese. 
Secondly, international scrutiny and international economic ties also matter. In the case of North Cyprus, Turkish support for or against the nationalist narrative proved vital. Meanwhile, vis-à-vis Taiwan, the support of the USA and the West, who acted as both sponsors and trade partners of the regime, were critical in determining whether Chinese nationalism stayed or whether Taiwanese nationalism arose due to their role as human rights watchdogs.

Thirdly, the intra-'us'-group divisions, their extent, and their nature matter greatly. The Northern Cypriots were divided along political lines vis-à-vis a potential resolution to the Cypriot Conflict, which was ethnicized as the fate of the Turkish immigrants and the future demographics of a united Cyprus were at stake. As such, the Turkish Cypriot community was further divided along pro-reintegration/Cypriotic and pro-status quo/Turkic lines. Such a polarization on incompatible grounds has long caused a decline of Turkish Cypriot democracy, where the essential public debate has been lost to the fear of Turkification or reintegration. Meanwhile, in Taiwan, the Chinese identity waned, as a group that was born and raised in the islands rather than the Mainland emerged and as external support to the KMT regime was pulled. Contrarily, the majoritarian, nativist nationalism took hold; however, as the majority was divided into three and the anti-China/pro-independence sentiment did not necessarily take deep roots, the 'us' was divided along 'policy' lines. Therefore, unlike the Northern Cypriot case, while the community was polarized to an extent, the nationalism aligned with civic principles. This was also aided by extensive trade relations with democratic partners.

\section{CONCLUSION: ATAVISTIC NATIONALISM AND POLICY CHOICES}

According to the present study, atavistic nationalism appears to arise only when there is a vacuum created by a systemic shock - be it diplomatic, militaristic, or economic - which has created a sense of threat and hopelessness among the populace at large. In the West and Asia, the economic crisis of 2008 and then of 2020 has precipitated this systemic shock. Indeed, as the globe experienced economic decline and thus relative deprivation, the promises of security and prosperity upon which multicultural democracy is based were perceived to have failed. Welfare chauvinism, coupled with skepticism regarding multiculturalism, meant that a new, more exclusive definition of 'us' became necessary 'to protect the community from the moochers/immigrants and the sell-out ideologues'. Facilitated by the post-9/11 global conjecture and inherent racism, the atavistic nationalism that we observe today was born from economic woes - real or perceived. Predatorial elites can capitalize on this opportunity of a need for atavism by stoking fears and promising illusive hope especially if these elites are symbolic of traditional power-holders that are not 'traditional elites'; most likely male and of a prominent background. 
Furthermore, if there are deep ideological, intragroup cleavages, there appears a higher likelihood that atavistic nationalism will not be widely adopted - such as in the case of Taiwan. However, if ethno-ideological divisions are persistent in the community, where the groups are relatively balanced in power, dysfunctional hyper-polarization along competing nationalist lines appears to become more probable, as in the case of NC. Lastly, in the case of elevated levels of intragroup homogeneity, atavistic nationalism seems to more easily take hold. Importantly, should atavistic nationalism become systemic, benefit networks, educational facilities, and media revolving around perpetuating the prominence of this narrative will be enacted and will have lasting effects.

The success of Taiwan in breaking away from destructive atavism - as well as the temporary success that Turkish Cypriots likewise saw in the early 2000s - can be attributed to extensive, positive engagement with the international community. Indeed, the more these states traded and/or entered a cooperation with democratic partners, the less they were likely to pursue unitary identities - especially when the economy thrived under plurality. As such, the international community should seek to reinforce interdependence - i.e. ties of economic and political cooperation - especially with those countries that appear susceptible to atavistic narratives.

Atavistic nationalism poses a threat to the political systems that we have come to take for granted - if the scholars and policymakers choose to ignore, isolate, or not engage with this type of narrative. However, such narratives do not necessarily lead to authoritarianism. While further cases must be explored to explain the systemic underpinnings of atavistic nationalism, the cases outlined in this article have shown two evolutionary possibilities of atavism. It will be up to the international community to choose where to go from here. 


\section{REFERENCES}

1. Bonikowski, Bart. 2016. "Nationalism in Settled Times." Annual Review of Sociology 42: 427-449.

2. Brudny, Yitzhak M., and Evgeny Finkel. 2011. "Why Ukraine Is Not Russia: Hegemonic National Identity and Democracy in Russia and Ukraine." East European Politics and Societies 25 (4): 813-33.

3. Chou, Yangsun, and Andrew Nathan. 1987. "Democratizing Transition in Taiwan." Maryland Series in Contemporary Asian Studies 3 (1). http://digitalcommons.law.umaryland.edu/mscas/vol1987/iss3/1.

4. Chu, Yun-han. 1996. "Taiwan's Unique Challenges." Journal of Democracy 7 (3): 69-82.

5. Chu, Yun-han, Larry Diamond, and Kharis Templeman, eds. 2016. Taiwan's Democracy Challenged: The Chen Shui-Bian Years. Boulder, Colorado: Lynne Rienner Publishers, Inc.

6. Conversi, Daniele. 2012. "Majoritarian Democracy and Globalization Versus Ethnic Diversity?" Democratization 19 (4): 789-811.

7. Diamond, Larry Jay. 2001. "How Democratic Is Taiwan? Five Key Challenges for Democratic Development and Consolidation." In . New York, NY: Columbia University.

8. Duzgun, Basaran. 2000. CakilTaslari: Kibris'tabirdoneminizdusumu (1990-2000). Istanbul, Turkey: Mart Matbaacilik.

9. Dyrstad, Karin. 2012. "After Ethnic Civil War: Ethno-Nationalism in the Western Balkans." Journal of Peace Research 49 (6): 817-31.

10. Freedom House. 2017. "Freedom In the World." Annual Report. Freedom and Liberties Across the World. Washington, DC: Freedom House.

11. Fukuyama, Francis. 1992. "Comments." Journal of Democracy 3 (4): 23-28.

12. Gingrich, Andre. 2006. "Neo-Nationalism and the Reconfiguration of Europe." Social Anthropology 14 (02): 195-217.

13. Gold, Thomas B. 1986. State and Society in the Taiwan Miracle. New York, N.Y.: M.E. Sharpe.

14. GrigorSuny, Ronald. 2017. "The Crisis of Bourgeois Democracy: The Fate of an Experiment in the Age of Nationalism, Populism, and Neo-Liberalism." New Perspectives on Turkey 57 (November): 115-41.

15. Isachenko, Daria. 2012. The Making of Informal States: Statebuilding in Northern Cyprus and Transdniestria. Rethinking Peace and Conflict Studies. Houndmills, Basingstoke, Hampshire; New York: Palgrave Macmillan.

16. Loizides, Neophytos G. 2015. Designing Peace: Cyprus and Institutional Innovations in Divided Societies. University of Pennsylvania Press. 
17. Mishra, Pankaj. 2017. Age of Anger: A History of the Present. New Yok, NY: Farrar, Straus and Giroux.

18. Mulaj, Klejda. 2011. "International Actions and the Making and Unmaking of Unrecognized States." In Unrecognized States in the International System, by Nina Caspersen and Gareth R. V. Stansfield, 41-57. Milton Park, Abingdon, Oxon ; New York: Routledge.

19. Navaro-Yashin, Yael. 2006. "De-Ethnicizing the Ethnography of Cyprus: Political and Social Conflict Between Turkish-Cypriots and Settlers from Turkey." In Divided Cyprus: Modernity and an Island in Conflict, edited by Yiannis Papadakis, NicosPeristianis, and Gisela Welz, 84-99. Bloomington, IN: Indiana University Press.

20. - 2012. The Make-Believe Space: Affective Geography in a Postwar Polity. Durham, NC: Duke University Press.

21. Phillips, Steven. 2016. "Democracy and National Destinies on Taiwan." Nations and Nationalism 22 (4): 666-85.

22. Sabatovych, lana. 2017. "Does Nationalism Promote Democracy? Comparative Analyses of Ukraine's 'Maidan' Revolution and Poland's 'Solidarity' Mass Mobilisation." Contemporary Politics, September, 1-22.

23. Surzhko-Harned, Lena. 2010. "Liberal Nationalism, Nationalist Liberalization, and Democracy: The Cases of Post-Soviet Estonia and Ukraine." Nationalities Papers 38 (5): 623-46.

24. The Economist. 2018. "Democracy Continues Its Disturbing Retreat," January 31, 2018. https://www.economist.com/blogs/graphicdetail/2018/01/daily-chart-21.

25. Verkhovskii, Aleksandr, and Emil Pain. 2012. "Civilizational Nationalism: The Russian Version of the 'Special Path.'" Russian Politics and Law 50 (5): 52-86.

26. Volkan, Vamik. 1998. Bloodlines: From Ethnic Pride to Ethnic Terrorism. New York, N.Y.: Farrar, Straus and Giroux.

27. Zuo, Yana. 2016. Evolving Identity Politics and Cross-Strait Relations: Bridging Theories of International Relations and Nationalism. New Perspectives on Cchinese Politics and Society. 